The CLASSICAL OUARTERLY and CLASSICAL REVIEW are the Organs of the Classical Association. The QUARTERLY is published in January, April, and October, the last issue being a double number; the REVIEW in February, May, July, September, November, and December.

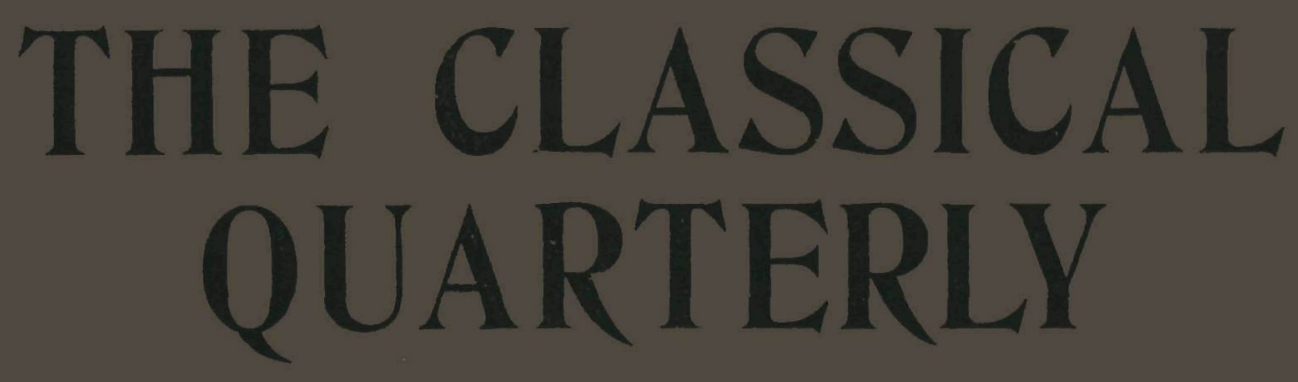

EDITED BY

F. W. HALL, M.A., St. John's College, Oxford.

R. HACKFORTH, M.A.,. Sidney Sussex College, Cambridge.

Board of Management:

Prof. J. F. DOBSON, M.A., Chaiman.

Prof, A. C. CLARE, Litt.D., F.B.A., Hon. Treaswrer.

L. WEIBLEY, M.A. Hon. Secretary.

Prof. R. S. CONWAY, ${ }_{\text {Litt.D., F.B.A. }}\left\{\begin{array}{l}\text { With the Chairmax, Trea. } \\ \text { surer, and Secretary, repre- }\end{array}\right.$

Prof. H. WILLIAMSON, M.A. $\int \begin{aligned} & \text { senting the Council } \\ & \text { Classical Association. }\end{aligned}$

J. BELL, M.A.

Refresenting the Orford Philological Society.

D. S. ROBERTSON, M.A.

Representing the Cambiridge Philolesical Society.

With the co-operation of Prof. WM. GARDNER HALR, University of Chicago:

Prof. Maurice Hutton, Toronto; Prof. T. G. Tucker, Litt. D., Melbourne.

Vol. XXII.

JANUARY, 1928

No. I

\title{
CONTENTS
}

Prosody and Method II.

A. E. Housman ${ }_{\text {I }}^{\text {I }}$

The Vatican Plato

L. A. Post II

'Imitation' in Plato's Republic . . . . . . . . . . . . . J. Tate i6

Lucan, Statius, Juvenal in Early Centuries . . . . . H. J. Thomson 24

Notes on Plotinus (II.) . . . . . . . . . . . . . J. H. Sleeman 28

The Hymn to Hermes. . . . . . . . . . . . . . . . . T. L. Agar 34

Hedonism in Plato's Protagoras . . . . . . . . . . . R. Hackforth 39

More Facts about Oldest Latin MSS. . . . . . . . . E. A. Lowe 43

Summaries of Periodicals . . . . . . . . . . . . . . . . . . . . . . 63

LONDON: JOHN MURRAY, ALBEMARLE STREET, W.

New York: G. E. STECHERT \& CO., 31-33, EAST готн STREET. 
EDITED BY

F. W. HALL, M.A.

AND

R. HACKFORTH, M.A.

Board of Management :

Prof. J. F. DOBSON, M.A., Chairman.

Prof, A. C. ClARK, Litt.D., F.B.A., Hon. Treasurer.

L. WHIBLEY, M.A., Hon. Secretary.

Prof. R. S. CON WAY, With the Chairman, TreaLitt.D., F.B.A. $\quad$ surer, and Secretary, repreProf. H. WILLIAMSON, senting the Council of the M.A.
E. A. BARBER, M.A. Representing the Oxford Philological Society.

D. S. ROBERTSON, M.A., Representing the Cambridge Philological Society.

With the co-operation of Prof. WM. GARDNER HALE, UnIversity of Chicago;

Prof. Maurice HUtTon, Toronto; Prof. T. G. TUCKER, Litt.D., Melbodrne.

\section{VOLUME XXII}

PUBLISHED FOR THE CLASSICAL ASSOCIATION BY

JOHN MURRAY, ALBEMARLE STREET, LONDON, W. AND

G. E. STECHERT छ CO., 3I-33, EAST IOTH STREET, NEW YORK 1928 
PRINTED IN GREAT BRIYAIN BY BILLING AND SONS, LTD., GULLDFORD AND ESHER 


\section{TABLE OF CONTENTS}

No. 1.

Prosody and Method II. A. E. Housman

The Vatican Plato. L. A. Post . . . . . . . . . II

'Imitation' in Plato's Republic. J. Tate . . . . . . . . . . . . 16

Lucan, Statius, Juvenal in Early Centuries. H. J. Tномson . . . . 24

Notes on Plotinus (II.). J. H. Sleeman . . . . . . . . . . . . $\quad .28$

The Hymn to Hermes. T. L. Agar . . . . . . . . . . 34

Hedonism in Plato's Protagovas. R. HACkforth . . . . . . . . 39

More Facts about Oldest Latin MSS. E. A. Lowe . . . . . . 43

Summaries of Periodicals :

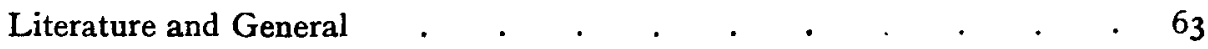

No. 2.

Horace and the Moral Function of Poetry. J. TATE $\quad$ - . . . . $\quad$. 65

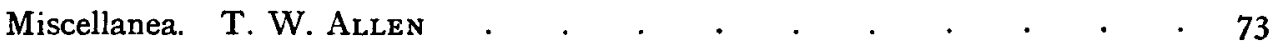

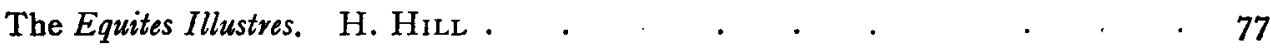

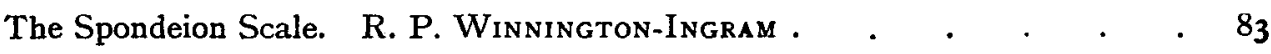

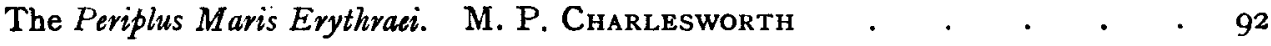

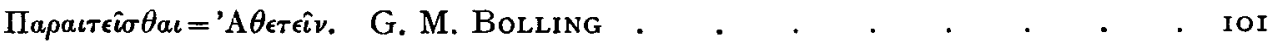

The Shorter Glosses of Placidus. J. W. PIRIE _ . . . . . . 107

Callimachus and Others. J. U. Powell .

Nicander's Signature, Questions without Answers. E. LoBEL . . . . II4

Notes on Festus and Terence. W. M. Lindsay $\quad$ - . . . . . . . . II7

Summaries of Periodicals:

Literature and General . . . . . . . . . 120

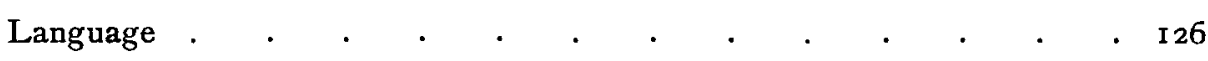




\section{Nos. 3, 4.}

The Parmenides of Plato and the Origin of the Neoplatonic 'One.' E. R. Dodds I 29

The Seventh and Eighth Platonic Epistles. J. Harward . . . . . I43

The Offerings of the Hyperboreans. C. T. Seltman . . . . . ${ }^{2} 55$

Alexander of Abonuteichos. A. D. Nock . . . . . . . . . . I60

The Pseudo-Aristotelian Problems: Their Nature and Composition. E. S.

Forster . . . . . . . . . . . . . 163

The Historia Augusta : Its Date and Purpose. Norman H. Baynes • . 166

Tacitus, Histories'I. I3. H. C. Nutring . . . . . . . . . . . 172

Zu P. Oxy. III. 4I4. S. LuRIA . . . . . . . . . . . . . I76

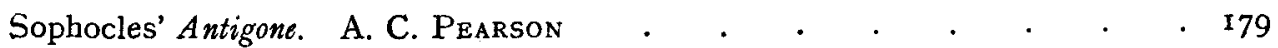

Martial V. xvii. 4. W. M. Lindsay . . . . . . . . . . IgI

March I, 50 в.c. C. G. Stone . . . . . . . . . . . . 193

Hands and Scribes. E. Lobel . . . . . . . . . . 202

Miscellanea II. T. W. Allen . . . . . . . . . . . 203

Karl Marx on Greek Atomism. Cyril Bailey . . . . . . . 205

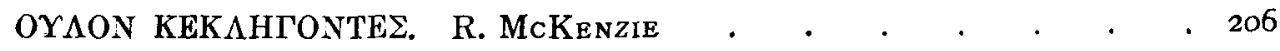

Aquilo, the Black Wind. R. McKenZIE . . . . . . . . 207

Summaries of Periodicals :

Literature and General $\quad . \quad$. . . . . . . 208

Language . . . . . . . . . . . . . . 214

Indices 